\title{
Burch Retropubic Urethropexy for Genuine Stress Urinary Incontinence: A Review of Eight Cases
}

\author{
${ }^{1}$ Disha A Rajput, ${ }^{2}$ Shalini M Valecha, ${ }^{3}$ Manisha Sarwade, ${ }^{4}$ Shrikant Dhumale
}

\begin{abstract}
Introduction: Urinary incontinence (UI) is more common than any other chronic disease with the prevalence of approximately 23 and $55 \%$. Among the various forms of $\mathrm{UI}$, stress incontinence (SUI) is the most common (49\%), with urgency incontinence (UUI) representing $21 \%$ and mixed type (MUI) at $29 \%$. As it affects the quality-of-life of women, the restoration of urinary continence is one of the greatest challenges.
\end{abstract}

Aim: To review the cases of genuine SUI treated surgically by Burch retropubic urethropexy.

Results: We have managed surgically eight cases of genuine SUI by Burch retropubic urethropexy. On 1-year follow-up, none of the patients had any urinary complaints. All had responded well to surgery and patient's satisfaction index was good.

Conclusion: Since SUI is the commonest among incontinences, it is a challenge to diagnose and treat to improve quality-of-life of patients. Burch retropubic urethropexy is the gold standard treatment for SUI, especially if other indications exist for abdominal surgery. Even in the present era of less invasive vaginal procedures, results are comparable.

Keywords: Burch, Retropubic space, Stress urinary incontinence.

How to cite this article: Rajput DA, Valecha SM, Sarwade M, Dhumale S. Burch Retropubic Urethropexy for Genuine Stress Urinary Incontinence: A Review of Eight Cases. J South Asian Feder Menopause Soc 2017;5(2):129-132.

Source of support: Nil

Conflict of interest: None

Date of received: 15 June 2017

Date of acceptance: 07 August 2017

Date of publication: December 2017

\section{INTRODUCTION}

Urinary incontinence affects 23 to $55 \%$ of women. ${ }^{1}$ The three most common types are SUI, UUI, and MUI. ${ }^{2}$ The SUI

\footnotetext{
${ }^{1}$ Associate Professor, ${ }^{2}$ Director Professor, ${ }^{3}$ Resident (Third Year) ${ }^{4}$ Resident (Second Year)

${ }^{1-4}$ Department of Obstetrics and Gynecology, ESI Post Graduate Institute of Medical Science and Research, ESC Model Hospital Mumbai, Maharashtra, India

Corresponding Author: Disha A Rajput, Associate Professor Department of Obstetrics and Gynecology, ESI Post Graduate Institute of Medical Science and Research, ESC Model Hospital Mumbai, Maharashtra, India, Phone: +912223003040, e-mail: disharajput@yahoo.co.in
}

is defined as the involuntary leakage of urine on effort or exertion, or on sneezing/coughing or, urodynamically, as the involuntary leakage of urine during increased abdominal pressure in the absence of a detrusor contraction.

Various studies have shown that the prevalence and types of UI are $49 \%$ of those affected have SUI, $21 \%$ have UUI, and 29\% have MUI. However, the prevalence of the different types of incontinences varies in older women. ${ }^{3}$

\section{CASE REPORT}

We have managed eight cases of genuine SUI with Burch retropubic urethropexy. History of all patients was taken in detail in respect of previous pregnancy, mode of delivery, any difficulty during delivery, instrumental delivery, or any complication during delivery like perineal tear, any history of chronic respiratory disorder, and any history of pelvic or spinal surgeries. All patients were thoroughly examined and investigated before surgery. On per speculum examination, they had hypermobile middle urethral segment. Details of all patients are tabulated in Table 1.

\section{DISCUSSION AND RESULTS}

\section{Pathophysiology}

The SUI is thought to be caused by a sphincteric abnormality, either urethral hypermobility or intrinsic sphincteric deficiency. The SUI is due to varying degrees of disruption of normal anatomy of urethra or due to scarring and fixation of these tissues. ${ }^{4}$ Magnetic resonant imaging (MRI) of women with SUI shows abnormalities like small urethral sphincter, funneling at the bladder neck, distortion of the urethral ligamentry support, cystocele, an asymmetric pubococcygeus muscle, abnormal shape of the vagina, enlargement of the retropubic space, and an increased vesicourethral angle. When intra-abdominal pressure increases, these abnormalities cause unequal movement of the anterior and posterior walls of the bladder neck, and urethra and urethral lumen are being pulled open as the posterior wall of the urethra moves away from the anterior wall. ${ }^{5,6}$

On cadaveric dissection, ventral and dorsal urethral ligaments have been identified.

The ventral urethral ligaments included the pubourethral ligaments, the periurethral ligament, and the paraurethral ligaments. Dorsal urethral ligament is a sling-like 


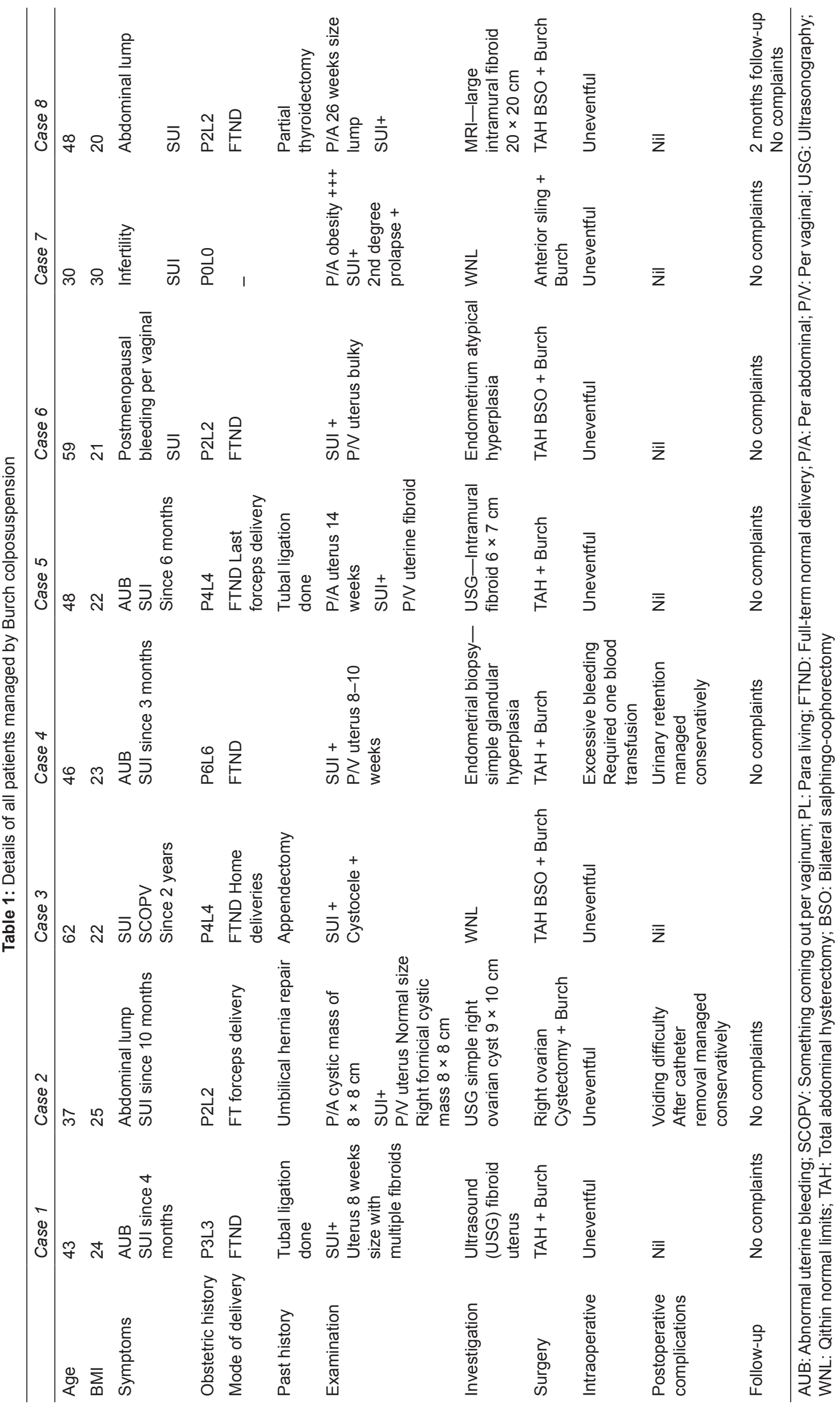


ligament "suburethral ligament". If these supporting ligaments become unstable, any increase in abdominal pressure can cause SUI. ${ }^{7}$

\section{Risk Factors for SUI}

Age, childbirth, postsurgery, chronic obstructive lung diseases, chronic weight lifting, pelvic radiation, obesity, neurogenic deceases, and congenital poor tissues are the notable risk factors. ${ }^{4}$

\section{Burch Retropubic Urethropexy}

Burch retropubic urethropexy was initially described in $1961 .^{8}$

The aim of surgery is to reestablish the intra-abdominal location of proximal urethra and the urethrovesical junction in retropubic space so as to minimize the descent of bladder neck and urethrovaginal junction when intraabdominal pressure increases.

\section{Procedure}

After exposure of the retropubic space as shown in Figure 1, the bladder neck and point of attachment of endopelvic

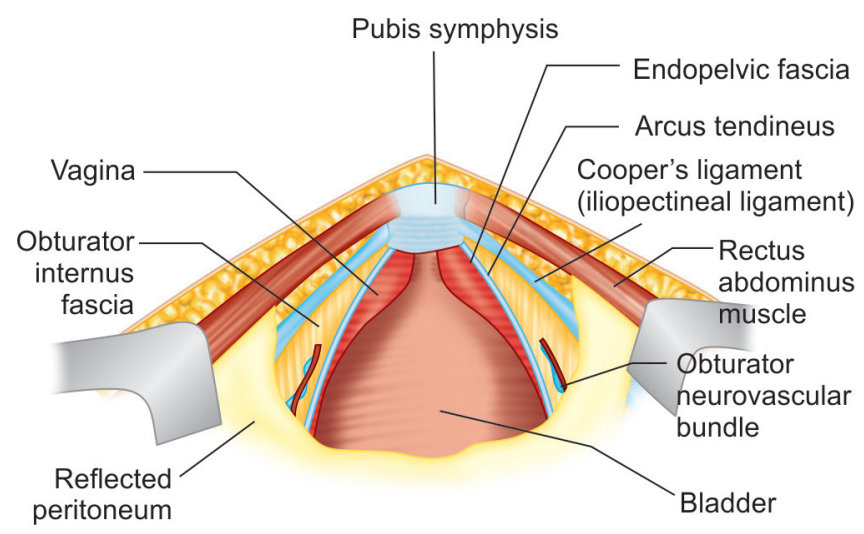

Fig. 1: Normal anatomy after dissection of retropubic space

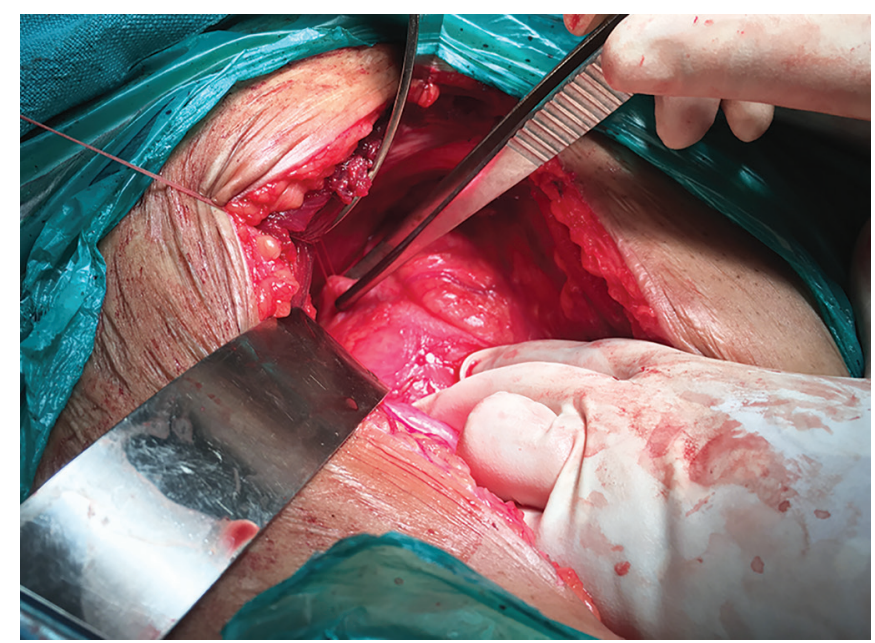

Fig. 2: Placement of suture in the vaginal wall at the level of bladder neck and passed through Cooper's ligament fascia are identified, especially the pubocervical fascia. Generally, two to three permanent sutures are placed on each side of the bladder neck. The first suture is placed in the vaginal wall at the level of the bladder neck and is passed through Cooper's ligament as shown in Figure 2. Subsequent sutures are placed proximal to the initial suture in a similar fashion. Once placed, the sutures are tied to suspend the bladder neck as in Figure 3. Burch retropubic urethropexy can also be performed laparoscopically. Cure rate is 85 to $90 \%$ at 1 to 5 years and more than $70 \%$ at 10 years. ${ }^{4}$

Two studies were conducted to evaluate long-term durability of the Burch retropubic urethropexy, with success observed in $69 \%$ of patients at 7.6 and 13.8 years. ${ }^{9}, 10$

Postoperative complications can be voiding dysfunction in $10.3 \%$ of patients, de novo detrusor instability in $17 \%$, and genitourinary prolapse in $13.6 \%$ of patients. ${ }^{11}$

Since SUI is the most common cause of UI, at about $49 \%$ of all incontinences, and as it affects the qualityof-life, ${ }^{3}$ it is really a challenge to diagnose and treat the condition appropriately. We have managed to set right eight cases of genuine SUI by Burch retropubic urethropexy, as these patients also needed abdominal surgeries for other indications.

In our case series, 6 out of 8 patients were multipara. Two were postmenopausal. All of them except one had full-term vaginal deliveries. Out of 8 patients, 2 had forceps delivery. Neither of them had any spinal surgery in the past nor did they have any chronic lung diseases. Seven patients had body mass index (BMI) in the range of 20 to 25, but one was obese. All eight patients had demonstrable SUI along with either abnormal uterine bleeding or lump in abdomen or vaginal prolapse. Intraoperatively, one patient had excessive bleeding, and dissection for which she required blood transfusion. Two patients had

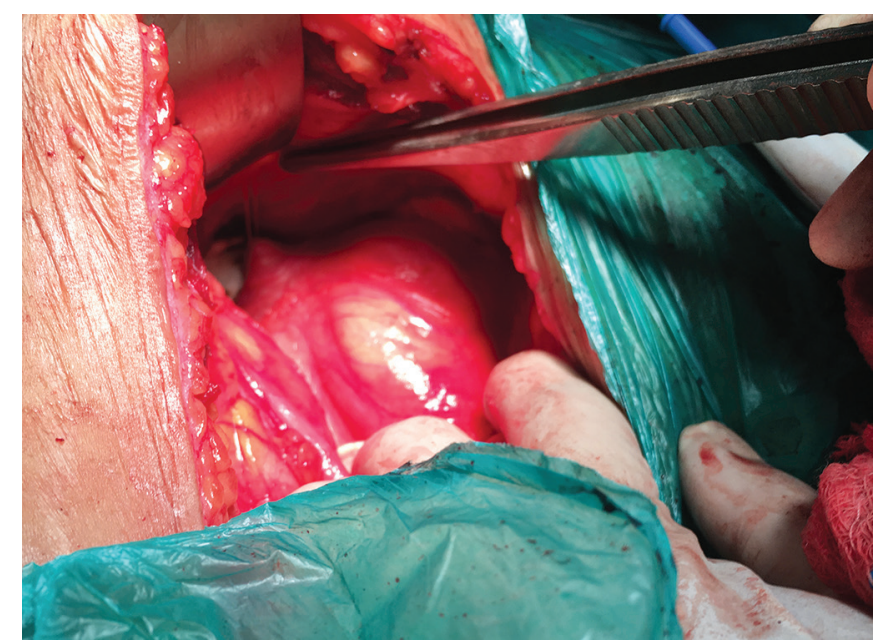

Fig. 3: Sutures are tied to suspend the bladder neck 
postoperative minor urinary complaints, and they were managed conservatively.

On 1-year follow-up, none of the patients had any urinary complaints. All had responded well to surgery and patient's satisfaction index was good.

\section{CONCLUSION}

Since SUI is the commonest among incontinences and it affects the quality-of-life of the patient, ${ }^{3}$ it is a challenge to diagnose and treat it appropriately to improve qualityof-life. Burch retropubic urethropexy is the gold standard treatment for SUI, especially, if other indications exist for abdominal surgery. Even in the present era of less invasive vaginal procedures, results are comparable with other alternatives. ${ }^{12,13}$ Though the procedure has a small learning curve, the results make it worth for the surgeons to learn it.

\section{REFERENCES}

1. Hunskaar S, Lose G, Sykes D, Voss S. The prevalence of urinary incontinence in women in four European countries. BJU Int 2004 Feb;93(3):324-330.

2. Abrams P, Cardozo L, Fall M, Griffiths D, Rosier P, Ulmsten U, van Kerrebroeck P, Victor A, Wein A, Standardisation Subcommittee of the International Continence Society. The standardisation of terminology of lower urinary tract function: report from the Standardisation Subcommittee of the International Continence Society. Neurourol Urodyn 2002 Mar;21(2):167-178.

3. Hunskaar, S.; Burgio, K.; Diokno, AC.;Herzog, AR.;Hjalmas, K.; Lapitan, MC. Epidemiology and natural history of urinary incontinence. In: Abrams PC, Khoury S, Wein A, editors. Incontinence: 2 nd international consultation on incontinence. Plymouth: Health Publication Ltd.; 2002. p. 165-201.
4. Bent, AE. Stress urinary incontinence. In: Rock JA, editor. Te Linde's operative gynaecology. 10th ed. Philadelphia (PA): Lippincott Williams and Wilkins; 2008. pp. 942-959.

5. Macura KJ, Genadry RR. Female urinary incontinence: pathophysiology, methods of evaluation and role of MR imaging. Abdom Imaging 2008 May-Jun;33(3):371-380.

6. Macura KJ, Genadry RR, BluemkeDA. MRimaging of the female urethra and supporting ligaments in assessment of urinary incontinence: spectrum of abnormalities. Radiographics 2006 Jul-Aug;26(4):1135-1149.

7. el-Sayed RF, Morsy MM, el-Mashed SM, Abdel-Azim MS. Anatomy of the urethral supporting ligaments defined by dissection, histology, and MRI of female cadavers and MRI of healthy nulliparous women. Am J Roentgenol 2007 Nov;189(5):1145-1157.

8. Burch JC. Urethrovaginal fixation to Cooper's ligament for correction of stress incontinence, cystocele and prolapse. Am J Obstet Gynecol 1961 Feb;81:281-289.

9. Drouin J, Tessier J, Bertrand PE, Schick E. Burch colpo-suspension: long-term results and review of published reports. Urology 1999 Nov;54(5):808-814.

10. Alcalay M, Monga A, Stanton SL. Burch colposuspension: a 10-20 year follow up. Br J Obstet Gynaecol 1995 Sep;102(9): 740-745.

11. Smith, T.; Daneshgari, F.; Dmochowski, R.; Ghoneim, G.; Jarvis, G.; Nitti, V.; Paraiso, MF. Surgical treatment of incontinence in women. In: Abrams PC, Khoury S, Wein A, editor. Incontinence: 2nd international consultation on incontinence. Plymouth: Health Publication Ltd.; 2002. p. 823-863.

12. Balmforth J, Cardozo LD. Trends toward less invasive treatment of female stress urinary incontinence. Urology 2003 Oct;62(4 Suppl 1):52-60.

13. Asıcıoglu O, Gungorduk K, Besımoglu B, Ertas IE, Yıldırım G, Celeb1 I, Ark C, Boran B. A-5 year follow-up study comparing Burch colposuspension and transobturator tape for the surgical treatment of stress urinary incontinence. Int J Gynaecol Obstet 2014 Apr; 125(1):73-77. 